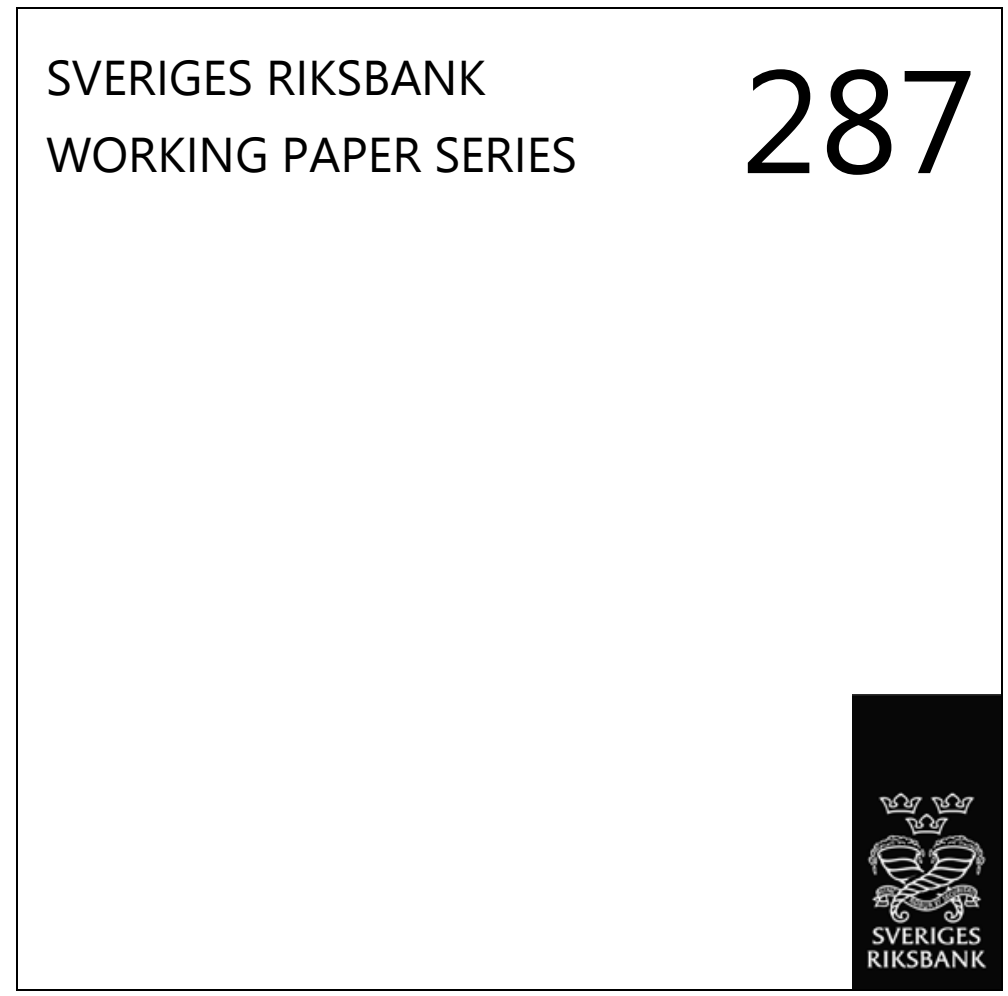

The Macro-Financial Implications of House Price-Indexed Mortgage Contracts

Isaiah Hull

September 2014 


\section{WORKING PAPERS ARE OBTAINABLE FROM}

Sveriges Riksbank • Information Riksbank • SE-103 37 Stockholm

Fax international: +4687870526

Telephone international: +4687870100

E-mail: info@riksbank.se

The Working Paper series presents reports on matters in the sphere of activities of the Riksbank that are considered to be of interest to a wider public.

The papers are to be regarded as reports on ongoing studies and the authors will be pleased to receive comments.

The views expressed in Working Papers are solely the responsibility of the authors and should not to be interpreted as reflecting the views of the Executive Board of Sveriges Riksbank. 


\title{
The Macro-Financial Implications of House Price-Indexed Mortgage Contracts
}

\author{
Isaiah Hull ${ }^{\dagger}$ \\ Sveriges Riksbank Working Paper Series \\ No. 287 \\ September 2014
}

\begin{abstract}
A standard, no-recourse mortgage contract does not adjust when the value of the underlying collateral falls. Consequently, shocks that lower house prices may trigger one of the necessary conditions for default: negative equity. A common alternative contract attempts to prevent default by imposing full-recourse. This may cause individuals who believe they are likely to default to rent; however, it does not prevent those who buy from experiencing negative equity. I consider a contract that instead precludes negative equity by tying outstanding debt to an index of house prices. This is done in an incomplete markets model that is calibrated to match U.S. micro and macro data. I find that switching to the houseprice indexed contract reduces the default rate from $.72 \%$ to $.11 \%$ and expands homeownership rates among the young and the poor, but pushes up the equilibrium minimum mortgage rate by 90 basis points. The volatility of net cashflows to financial intermediaries also increases slightly under the new contract.
\end{abstract}

JEL Classification: G21, E21, E43

Keywords: Default, Mortgages, Interest Rates, Heterogeneous Agents, Incomplete Markets

The views expressed in this paper are solely the responsibility of the author and should not be interpreted as reflecting the views of the Executive Board of Sveriges Riksbank.

${ }^{\dagger}$ Research Division, Sveriges Riksbank, SE-103 37, Stockholm, Sweden. Email: isaiah.hull@riksbank.se. 


\section{Introduction}

A standard, no-recourse mortgage does not adjust its terms when the value of the underlying collateral changes. One consequence of this contract structure is that large reductions in house prices will cause households to have negative equity. Recent empirical work suggests that negative equity, coupled with unemployment and a weak asset position, leads to mortgage default. ${ }^{1}$

Consequently, a contract that adjusts with house prices to prevent negative equity will preclude default. This is accomplished by shifting the burden of the house price reduction to the lender. If house prices drop and a household is hit with an income shock simultaneously, she can sell, rather than defaulting. Under a standard contract, a household that experiences the same set of shocks can neither sell nor make payments, resulting in a breach of contract that initiates the foreclosure process.

In the following section, I setup an incomplete markets model in the style of Bewley (1983) and Aiyagari (1994) that features mortgage default. The model will not have aggregate uncertainty, as in Krusell and Smith (1998), but will emulate it in a stationary model by constructing regions that experience idiosyncratic shocks to housing productivity. This second tier of idiosyncratic shocks (above households, but below the aggregate economy) makes it possible to create localized credit crunches, as default probabilities and house price movements comove within a region. I then solve and simulate the model under two classes of contracts: 1) a standard, no-recourse mortgage contract; and 2) an alternative, house-price indexed (HPI) contract, which is constructed to eliminate negative equity.

\section{The Model}

\subsection{Firms}

The firm side of the economy consists of 1 ) a consumption goods producer who rents labor services; and 2) a region-specific technology that permits all households to transform the consumption good into housing units.

\subsubsection{Consumption Goods}

Consumption goods are produced using labor and are subject to decreasing returns:

$$
Y_{t}=N_{t}^{\alpha}
$$

Firms maximize profits, yielding the factor price for labor, where $N_{t}$ is the mass of employed workers:

$$
w_{t}=\alpha N_{t}^{\alpha-1}
$$

\subsubsection{Housing Investment}

The housing production specification is based on Glover, Heathcote, Krueger, and RiosRull (2011), but allows for regional heterogeneity. Agents in each region have access to a

\footnotetext{
${ }^{1}$ See Gerardi, Herkenhoff, Ohanian, and Willen (2013); Foote, Gerardi, and Willen (2008).
} 
linear technology that transforms the consumption good into housing. If agent $\mathrm{i}$ in region m builds with $c_{m i t}^{h}$ units of the consumption good, it will yield $i h_{m i t}^{m}$ new units of housing:

$$
i h_{m i t}^{m}=c_{m i t}^{h} e^{U_{m t}},
$$

where $U_{m t}=u_{H}+\rho_{H} U_{m t-1}+\epsilon_{m H}, \epsilon_{H} \sim N\left(0, \sigma_{m H}\right)$. Total housing investment can be written as follows:

$$
I H_{t}=\sum_{i \in I} \sum_{m \in M} c_{m i t}^{h} e^{U_{m t}} \mu_{m i},
$$

where $\mu_{m i}$ is agent $\mathrm{i}$ in region m's mass and where $I H_{t}$ denotes the aggregate. The housing stock evolves as follows:

$$
H_{t+1}=H_{t}+I H_{t}-\delta_{H} H_{t},
$$

where $\delta_{H}$ is housing stock depreciation.

\subsection{Households}

Households work for $T^{W}$ periods and then retire. An employed household that is age a and productivity type $\mathrm{g}$ at time $\mathrm{t}$ receives a wage, $w_{t} \eta_{a g}$, where $\eta_{a g}$ is productivity weight of age cohort a and permanent productivity type g. Unemployed and retired agents receive a transfer payment from the government, $x_{t}$. Households pay an age and productivity-specific tax, $\Gamma_{i t}$, which yields the following income process:

$$
y_{i t}= \begin{cases}w_{t} n_{a_{i t}}-\Gamma_{a t} & \text { if employed } \\ x_{t} & \text { if unemployed or retired }\end{cases}
$$

Households consume two types of goods: 1) non-durable goods, which serve as the numeraire; and 2) service flows from housing, which are proportional to the size of the housing stock, $h_{i t}$ :

$$
u\left(c_{i t}, h_{i t}\right)=\frac{c_{i t}^{1-\sigma_{c}}}{1-\sigma_{c}}+\frac{h_{i t}^{1-\sigma_{h}}}{1-\sigma_{h}}
$$

Households also accumulate bank deposits, borrow in the form of collateralized mortgages, and choose whether or not to default on mortgage debt, yielding the following budget constraint:

$$
\begin{array}{r}
c_{i t}+\phi\left(h_{i t}, h_{i t-1}\right)+d_{i t}+p_{t}^{h} h_{i t}+m_{i t}=y_{i t}+(1+r) d_{i t-1}+ \\
p_{m t} h_{i t-1}\left(1-\delta_{H}\right)+b_{i t}
\end{array}
$$

Note that $p_{t}^{h}$ is the relative price of housing, $m_{i t}$ is the mortgage payment, and $b_{i t}$ is the unpaid balance on the mortgage.

Households face a concave adjustment cost, $\phi\left(h_{i t}, h_{i t-1}\right)$, which generates lumpy investment (i.e. infrequent moves). As in Iacoviello and Pavan (2011), there is a minimum house size, $\bar{h}$; and agents who cannot own have access to a small, fixed amount of nonhousing shelter.

Additionally, I apply a novel constraint that makes holders of one-period mortgages behave as if they held long term debt: 


$$
b_{i t}^{H} \leq \begin{cases}\lambda p_{t}^{h} h_{i t} & \text { if } h_{i t}-h_{i t-1}>0 \\ \lambda p_{t}^{h} h_{i t} & \text { if } b_{i t-1}<\lambda p_{t} h_{i t} \& h_{i t}=h_{i t-1} \\ b_{i t-1} & \text { otherwise }\end{cases}
$$

where $\lambda \in(0,1)$ denotes the maximum loan-to-value ratio.

The intent of this constraint is to achieve the following: 1) prevent spurious defaults that arise from one-period contracts with a collateral constraint; 2) permit mortgage equity withdrawal; and 3) allow negative equity.

I also borrow a constraint from Iacoviello and Pavan (2011) that limits borrowing to a fraction, $\gamma$, of discounted, remaining lifetime earnings:

$$
b_{i t}^{I}=\gamma E_{t} \sum_{j=t}^{T-a+j} \beta^{T-a+t} y_{i j}
$$

The final constraint combines the previous two:

$$
b_{i t} \leq \min \left\{b_{i t}^{H}, b_{i t}^{I}\right\}
$$

That is, the maximum amount a household can borrow is the minimum implied by the two borrowing constraints.

Deposits yield the equilibrium interest rate, $r$, and borrowers pay an individual-specific mortgage rate, $\xi_{i t}$, which depends on the contract structure. Defaulters forfeit their housing stock and are temporarily excluded from the mortgage market.

With the choice problem fully specified, we may collect the state variables, $z_{i m t}=$ $\left\{d_{i t-1}, \psi_{i t}, h_{i t-1}, b_{i t-1}, \epsilon_{i t}, a_{i t}, g_{i}, r, p_{m t}^{h}\right\}$ and the parameters

$\Omega=\left\{\alpha, \sigma_{h}, \gamma, \lambda, \rho_{m U}, \sigma_{m U}, \delta_{h}\right\}$ to simplify notation. The dynamic programming problem (DPP) for the household, subject to equations 1-11, may be written as follows:

$$
\begin{gathered}
V_{i t}\left(z_{i t} ; \Omega\right)=\max _{\left\{c_{i t}, d_{i t}, k_{i t}, h_{i t}, b_{i t}, \psi_{i t}^{d}\right\}} u\left(c_{i t}, h_{i t}\right)+ \\
\beta \sum_{\epsilon^{E \prime} \in\{1,0\}} \operatorname{Pr}\left(U^{\prime}\right) \operatorname{Pr}\left(\epsilon^{E \prime} \mid \epsilon^{E}\right) V_{i t+1}\left(z_{i t+1} ; \Omega\right)
\end{gathered}
$$

\subsection{The Financial Intermediary}

The market for financial intermediation is perfectly competitive. All mortgages originated yield zero profits on average in equilibrium. Two equilibria are considered: one with the standard contract and another with the HPI contract.

\subsubsection{Standard Mortgage Contract}

We assume that the foreclosure process is costly and that financial intermediaries only recover a fraction, $\Lambda<1$, of the outstanding debt from defaulters. Thus, a contract must be priced to satisfy the following condition:

$$
(1+r) b_{i t-1}=\left(1-q_{i t-1}\right)\left(1+\xi_{i t}\right) b_{i t-1}+q_{i t-1} b_{i t-1} \Lambda
$$

Here, $q_{i t-1}$ is the rational expectations probability of default. This implies the following, borrower-specific mortgage rate: 


$$
\xi_{i t}=\frac{r+(1-\Lambda) q_{i t-1}}{1-q_{i t-1}}-1
$$

The equilibrium interest rate on deposits, $r$, clears the mortgage market by equating aggregate savings and mortgage debt.

Using these assumptions, the intermediary sets the mortgage payment for household $\mathrm{i}$, who obtained a loan in period $\mathrm{t}$ as follows:

$$
m_{i t}=\left(1+\xi_{i t}\right) b_{i t-1}
$$

If a household defaults, it repays neither principal nor interest on the mortgage.

\subsubsection{HPI Contract}

In the alternative contract, outstanding debt is indexed to the regional house price level. This contract specification eliminates one of the necessary conditions for default: negative equity. The mortgage payment is as follows:

$$
m_{i t}=\left(1+\xi_{i t}\right) \min \left\{b_{i t-1}, p_{t}^{h} b_{i t-1}\left(1-\delta_{h}\right)\right\}
$$

This contract requires the following condition to be satisfied:

$$
(1+r) b_{i t-1}=\left(1+\xi_{i t}\right) \min \left\{b_{i t-1}, p_{t}^{h} h_{i t-1}\left(1-\delta_{h}\right)\right\}
$$

This can be rewritten to yield the individual-specific mortgage rate:

$$
\xi_{i t}=\frac{1+r}{\min \left\{1, \frac{p^{h} b_{i t-1}\left(1-\delta_{h}\right)}{b_{i t-1}}\right\}}-1
$$

Note that indexing only takes effect when house prices fall; and when it takes effect, it reduces the size of the payment and the amount of debt outstanding.

\subsection{The Government}

The government makes transfer payments to retired and unemployed individuals at a constant replacement ratio, $\zeta$. It collects taxes from employed agents that are proportional to income; and maintains a balanced budget in all periods.

\subsection{Aggregate Consistency Conditions}

The economy is also subject to a set of standard aggregate consistency conditions. Additionally, the equilibrium interest rate must clear the mortgage market.

\subsection{Calibration}

The model's calibration is given in Table 1. The utility function was parameterized according to Chambers et. al (2009). The standard deviation for the housing productivity process applies only at the regional level, as there is no aggregate variation. The housing adjustment cost, housing depreciation rate, max lifetime borrowing parameter, and 
minimum house size is taken from Iacoviello and Pavan (2011). The within-cohort productivity range is calibrated to target an after-tax wage-GINI coefficient of 0.30 . The quantity of non-housing shelter is used to calibrate the default rate for the standard contract. Additionally, micro data from the CPS is used to calibrate wage-age profiles.

Table 1: Model Calibration

\begin{tabular}{lll}
\hline & Param & Value \\
\hline \hline Housing utility curvature & $\sigma_{H}$ & 3 \\
Cons. utility curvature & $\sigma_{C}$ & 1 \\
Regional housing prod. persistence & $\rho_{H}$ & .60 \\
St. dev. housing prod. & $\sigma_{H}$ & 0.15 \\
Within-cohort productivity range & - & {$[0.7,1.3]$} \\
Non-housing shelter & - & $1.0 \times \mathrm{W}$ \\
Unemployment rate & - & $6.1 \%$ \\
Housing depreciation rate & - & .05 \\
Housing adjustment cost & - & .05 \\
Max LTV ratio & $\lambda$ & 1.00 \\
Max lifetime borrowing & $\gamma$ & .35 \\
Replacement ratio & $\zeta$ & .4 \\
Min house size & $\underline{\mathrm{h}}$ & $1.5 \mathrm{x} \mathrm{W}$ \\
Labor share & $\alpha$ & .67 \\
Discount factor & $\beta$ & .95 \\
Housing recovered in foreclosure & $\Lambda$ & 0.70 \\
\hline
\end{tabular}

\section{Results}

We will first consider the aggregate results for the model, given in Table 2. These were computed by averaging over 2,400,000 agent-periods of simulated data.

Table 2: Aggregate Differences Across Contracts

\begin{tabular}{llll}
\hline & Standard & Alternative & Difference \\
\hline \hline Default & $0.72 \%$ & $0.11 \%$ & $0.61 \mathrm{ppt}$ \\
Consumption & 0.527 & 0.558 & $5.88 \%$ \\
Borrowing & 0.541 & 0.7962 & $47.19 \%$ \\
Mortgage Rate & $1.0414 \%$ & $1.0504 \%$ & $90 \mathrm{bp}$ \\
LTV Ratio & $86.30 \%$ & $92.51 \%$ & $6.21 \mathrm{ppt}$ \\
\hline
\end{tabular}

The switch from the standard to HPI contract reduces the default rate from $0.72 \%$ to $0.11 \%$. It does not drop to zero, however, because some households are unable to repay both principal and interest, even if they can sell to repay principal. The switch also increases consumption by $5.88 \%$, partly by reducing reliance on the costly foreclosure process. Borrowing increases, driven by lending to young and low income households, which is documented further in Figure 1. This pushes up the equilibrium interest rate by 90bp.

Next, we consider the differences in lifecycle profiles across contract types. Figure 1 uses the same simulated data, but does not aggregate across age. Notice that young households benefit disproportionately from the option to borrow more without increasing 
Figure 1: Average Lifecycle Profile Differences

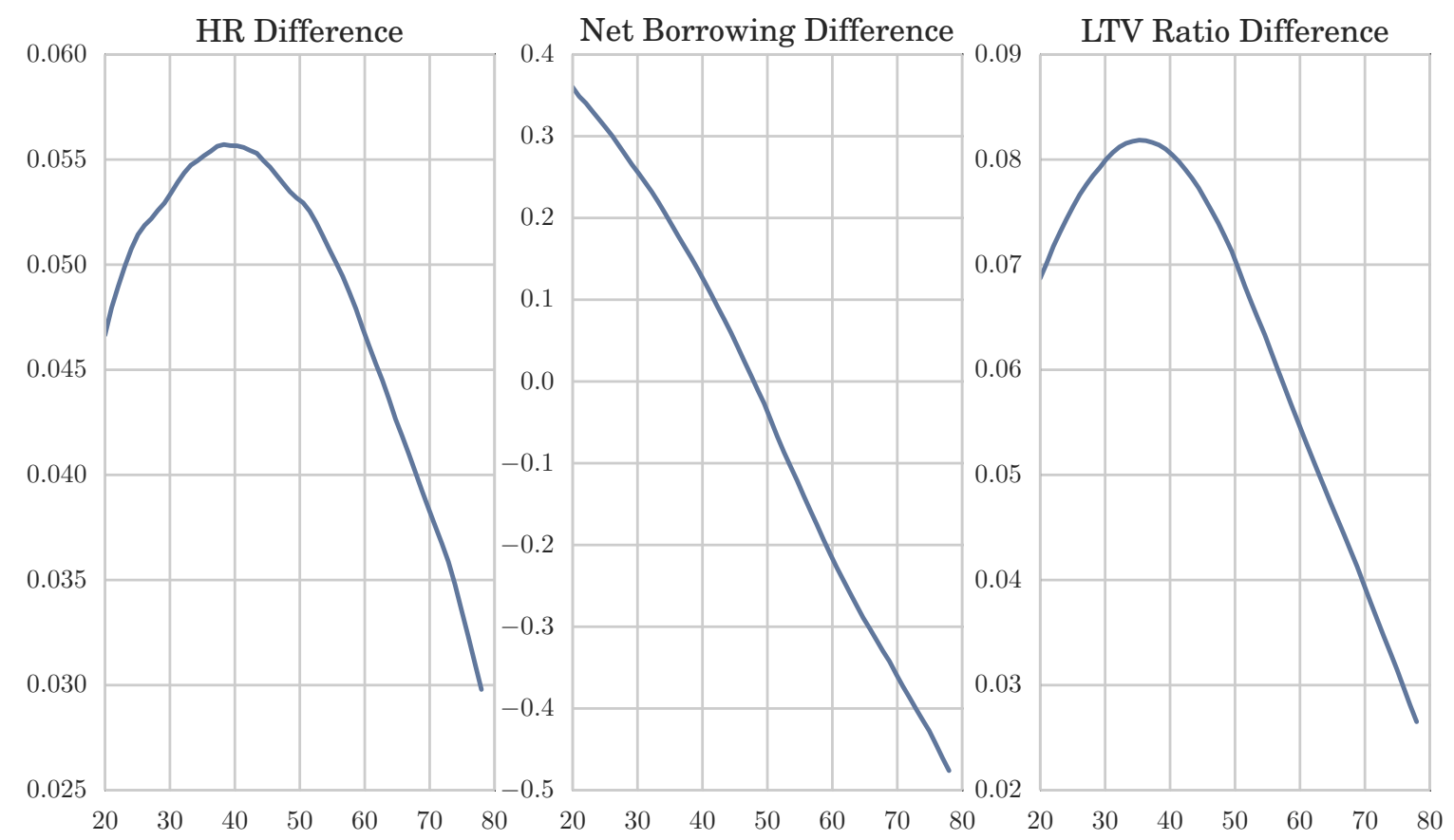

their probability of default or the associated risk premium on their mortgage. This induces a rise in the LTV ratio. Homeownership also disproportionately rises for low productivity households (not shown in the figure), who see a gain that is 10ppt higher than the corresponding rise for high productivity agents.

Figure 2 shows the simulated CDFs for net cashflows for each time-region pair. Each region receives a different sequence of exogenous shocks from the housing productivity process. This generates variation in the rate of default under the standard contract and variation in contract revaluation under the HPI contract. The HPI contract has a slightly higher mass in both tails, suggesting that it increases the regional dispersion of cashflows.

\section{Conclusion}

I use an incomplete markets model with mortgage default to study house price-indexed (HPI) mortgage contracts. When house prices fall, the amount of outstanding debt falls, precluding negative equity, which is a necessary condition for default. I find that switching to the HPI contract reduced the default rate in the model from .72\% to .11\%, but increased the equilibrium minimum mortgage rate by 90 basis points. The new contract also expanded homeownership in all age groups, but had a particularly pronounced impact on young and low income households.

Beyond the properties identified in this paper, the HPI contract has two additional benefits: first, it assigns clearer roles to originators and borrowers by incorporating more contingencies into the contract, rather than allowing those contingencies to result in a breach of contract. And second, it explicitly reassigns the need to forecast regional house prices from laypersons to financial institutions. 
Figure 2: CDF of Financial Intermediary Net Cashflows

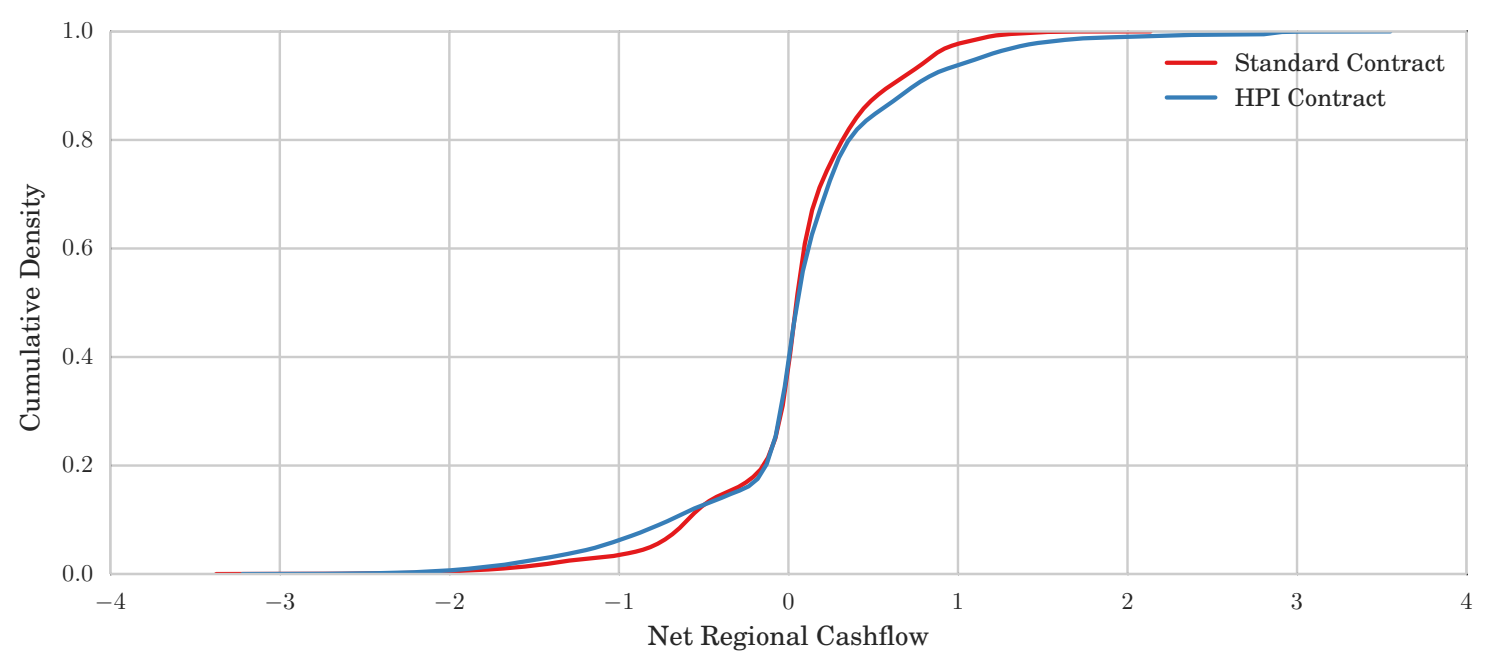

\section{References}

Aiyagari, R., 1994. Uninsured idiosyncratic risk and aggregate saving. The Quarterly Journal of Economics 109(3), 659-84.

Bewley T., 1983. A difficulty with the optimum quantity of money. Econometrica 51(5), $1485-504$.

Chambers, M., Garriga, C. \& Schlagenhauf, D., 2009. The loan structure and housing tenure decisions in an equilibrium model of mortgage choice. Review of Economic Dynamics 12(3), 444-468.

Foote, C., \& Willen, P., 2008. Negative equity and foreclosure: theory and evidence. Journal of Urban Economics, 64(2): 234-245.

Gerardi, K., Herkenhoff, K., Ohanian, L., \& Willen, P., 2013. Unemployment, negative equity, and strategic default. Federal Reserve Bank of Atlanta Working Paper Series, WP 2013-04.

Glover, A., Heathcote, J., Krueger, D., \& Rios-Rull, V., 2011. Intergenerational redistribution in the great recession. NBER Working Papers 16924, National Bureau of Economic Research, Inc.

Iacoviello, M., \& Pavan, M., 2011. Housing and debt over the life cycle and over the business cycle. Working Papers 2011/04, Economics Department, Universitat Jaume I, Castellon (Spain).

Krusell, P., Smith, A., 1998. Income and wealth heterogeneity in the macroeconomy. Journal of Political Economy 106(5), 867-896.

Mian, A., \& Sufi, A., 2011. House prices, home equity-based borrowing, and the US 
household leverage crisis. American Economic Review 101(5), 2132-56. 


\section{Earlier Working Papers:}

For a complete list of Working Papers published by Sveriges Riksbank, see www.riksbank.se

Estimation of an Adaptive Stock Market Model with Heterogeneous Agents

Some Further Evidence on Interest-Rate Smoothing: The Role of Measurement Errors in the Output Gap

by Mikael Apel and Per Jansson

Bayesian Estimation of an Open Economy DSGE Model with Incomplete Pass-Through

by Malin Adolfson, Stefan Laséen, Jesper Lindé and Mattias Villani

Are Constant Interest Rate Forecasts Modest Interventions? Evidence from an Estimated Open Economy

DSGE Model of the Euro Area

by Malin Adolfson, Stefan Laséen, Jesper Lindé and Mattias Villani

Inference in Vector Autoregressive Models with an Informative Prior on the Steady State by Mattias Villani

Bank Mergers, Competition and Liquidity

by Elena Carletti, Philipp Hartmann and Giancarlo Spagnolo

Testing Near-Rationality using Detailed Survey Data

by Michael F. Bryan and Stefan Palmqvist

Exploring Interactions between Real Activity and the Financial Stance

by Tor Jacobson, Jesper Lindé and Kasper Roszbach

Two-Sided Network Effects, Bank Interchange Fees, and the Allocation of Fixed Costs

by Mats $A$. Bergman

Trade Deficits in the Baltic States: How Long Will the Party Last?

by Rudolfs Bems and Kristian Jönsson

Real Exchange Rate and Consumption Fluctuations follwing Trade Liberalization

by Kristian Jönsson

Modern Forecasting Models in Action: Improving Macroeconomic Analyses at Central Banks

by Malin Adolfson, Michael K. Andersson, Jesper Lindé, Mattias Villani and Anders Vredin

Bayesian Inference of General Linear Restrictions on the Cointegration Space

2005:184

by Mattias Villani

Forecasting Performance of an Open Economy Dynamic Stochastic General Equilibrium Model

by Malin Adolfson, Stefan Laséen, Jesper Lindé and Mattias Villani

Forecast Combination and Model Averaging using Predictive Measures by Jana Eklund and Sune Karlsson

Swedish Intervention and the Krona Float, 1993-2002

by Owen F. Humpage and Javiera Ragnartz

A Simultaneous Model of the Swedish Krona, the US Dollar and the Euro

2005:185

by Hans Lindblad and Peter Sellin

Testing Theories of Job Creation: Does Supply Create Its Own Demand?

by Mikael Carlsson, Stefan Eriksson and Nils Gottfries

Down or Out: Assessing The Welfare Costs of Household Investment Mistakes

by Laurent E. Calvet, John Y. Campbell and Paolo Sodini

Efficient Bayesian Inference for Multiple Change-Point and Mixture Innovation Models

by Paolo Giordani and Robert Kohn

Derivation and Estimation of a New Keynesian Phillips Curve in a Small Open Economy

by Karolina Holmberg

Technology Shocks and the Labour-Input Response: Evidence from Firm-Level Data

by Mikael Carlsson and Jon Smedsaas

Monetary Policy and Staggered Wage Bargaining when Prices are Sticky

2005:188

by Mikael Carlsson and Andreas Westermark

The Swedish External Position and the Krona

2005:189

2005:190

2005:191

2006:192

$2006: 193$

$\ldots$

2006:194

2006:195

2006:196

2006:197

2006:198

by Philip R. Lane 
Using a New Open Economy Macroeconomics model to make real nominal exchange rate forecasts 
Evaluating Microfoundations for Aggregate Price Rigidities: Evidence from Matched Firm-Level Data on

Flexible Modeling of Conditional Distributions Using Smooth Mixtures of Asymmetric

Student T Densities

by Feng Li, Mattias Villani and Robert Kohn

Forecasting Macroeconomic Time Series with Locally Adaptive Signal Extraction

Risk Premiums and Macroeconomic Dynamics in a Heterogeneous Agent Model by Ferre De Graeve, Maarten Dossche, Marina Emiris, Henri Sneessens and Raf Wouters

Picking the Brains of MPC Members

by Mikael Apel, Carl Andreas Claussen and Petra Lennartsdotter

Involuntary Unemployment and the Business Cycle

by Lawrence J. Christiano, Mathias Trabandt and Karl Walentin

Housing collateral and the monetary transmission mechanism

by Karl Walentin and Peter Sellin

The Discursive Dilemma in Monetary Policy

by Carl Andreas Claussen and Øistein Røisland

Monetary Regime Change and Business Cycles

Bayesian Inference in Structural Second-Price common Value Auctions

by Bertil Wegmann and Mattias Villani

Equilibrium asset prices and the wealth distribution with inattentive consumers

by Luca Sala, Ulf Söderström and Antonella Trigari

Density-Conditional Forecasts in Dynamic Multivariate Models

by Michael K. Andersson, Stefan Palmqvist and Daniel F. Waggoner

Anticipated Alternative Policy-Rate Paths in Policy Simulations

by Stefan Laséen and Lars E. O. Svensson

MOSES: Model of Swedish Economic Studies

by Gunnar Bårdsen, Ard den Reijer, Patrik Jonasson and Ragnar Nymoen

The Effects of Endogenuos Firm Exit on Business Cycle Dynamics and Optimal Fiscal Policy

by Lauri Vilmi

Parameter Identification in a Estimated New Keynesian Open Economy Model 
The Cost of Consumer Payments in Sweden

by Björn Segendorf and Thomas Jansson

Trade Credit and the Propagation of Corporate Failure: An Empirical Analysis

by Tor Jacobson and Erik von Schedvin

Structural and Cyclical Forces in the Labor Market During the Great Recession: Cross-Country Evidence

by Luca Sala, Ulf Söderström and AntonellaTrigari

Pension Wealth and Household Savings in Europe: Evidence from SHARELIFE

by Rob Alessie, Viola Angelini and Peter van Santen

Long-Term Relationship Bargaining

by Andreas Westermark

Using Financial Markets To Estimate the Macro Effects of Monetary Policy: An Impact-Identified FAVAR*

by Stefan Pitschner

DYNAMIC MIXTURE-OF-EXPERTS MODELS FOR LONGITUDINAL AND DISCRETE-TIME SURVIVAL DATA

by Matias Quiroz and Mattias Villani

Conditional euro area sovereign default risk

by André Lucas, Bernd Schwaab and Xin Zhang

Nominal GDP Targeting and the Zero Lower Bound: Should We Abandon Inflation Targeting?*

by Roberto M. Billi

Un-truncating VARs*

by Ferre De Graeve and Andreas Westermark

Housing Choices and Labor Income Risk

by Thomas Jansson

Identifying Fiscal Inflation*

by Ferre De Graeve and Virginia Queijo von Heideken

On the Redistributive Effects of Inflation: an International Perspective*

by Paola Boel

Business Cycle Implications of Mortgage Spreads* 
Firm-Level Evidence of Shifts in the Supply of Credit

2013:280

by Karolina Holmberg

Lines of Credit and Investment: Firm-Level Evidence of Real Effects of the Financial Crisis

by Karolina Holmberg

A wake-up call: information contagion and strategic uncertainty

by Toni Ahnert and Christoph Bertsch

Debt Dynamics and Monetary Policy: A Note

2013:283

by Stefan Laséen and Ingvar Strid

Optimal taxation with home production

2014:284

by Conny Olovsson

Incompatible European Partners? Cultural Predispositions and Household Financial Behavior

$2014: 285$

by Michael Haliassos, Thomas Jansson and Yigitcan Karabulut

How Subprime Borrowers and Mortgage Brokers Shared the Piecial Behavior

2014:286

by Antje Berndt, Burton Hollifield and Patrik Sandås 
Sveriges Riksbank

Visiting address: Brunkebergs torg 11

Mail address: se-103 37 Stockholm

Website: www.riksbank.se

SVERIGES Telephone: +46 878700 00, Fax: +46 8210531

RIKSBANK E-mail: registratorn@riksbank.se 